\title{
Texture Profile and Pectinase Activity in Tomato Fruit (Solanum lycopersicum, Servo F1) at Different Maturity Stages and Storage Temperatures
}

DOI: $10.18196 /$ pt.v9i1.9139

\author{
Angesom Asgele Gebregziabher ${ }^{1}$, Supriyadi Supriyadi ${ }^{1 *}$, Siwi Indarti ${ }^{2}$, Lilis Setyowati ${ }^{2}$ \\ ${ }^{1}$ Department of Food Science and Technology, Faculty of Agricultural Technology, Universitas Gadjah Mada, \\ Jl. Flora 1 Bulaksumur, Yogyakarta 55281, Indonesia \\ ${ }^{2}$ Pusat Inovasi Agroteknologi (PIAT), Universitas Gadjah Mada, Jl. Tanjungtirto, Kalitirto, Yogyakarta 55573, Indonesia \\ *Corresponding author, email: suprif248@ugm.ac.id
}

\begin{abstract}
The demand for daily consumption of tomato fruit is increasing immensely. Nevertheless, the fruit is exposed to mechanical damage, shrinking, and softening as the maturity stages, handling, and storage are inappropriate, thereby affecting the texture. The study aimed to assess the texture profile, pectinase activity, and physicochemical parameters in tomato fruit at different maturity stages and storage temperatures. The fruits were harvested at 1-4 weeks after pollination and stored at a temperature of $16^{\circ} \mathrm{C}$ and $25^{\circ} \mathrm{C}$. There was an increase in the redness color (a*), TSS content, weight loss, respiration rate, and ethylene production, while the hardness, lightness color $\left(L^{*}\right), \mathrm{pH}$, and TA decreased with an increase in maturity stages at different storage temperatures. The higher Polygalacturonase (PG) and Pectin methylesterase (PME) enzyme activities were observed at $25^{\circ} \mathrm{C}$ compared to storage temperature of 16 ${ }^{\circ} \mathrm{C}$. It was confirmed that pectinase activity extremely affected the texture profile. For commercial purposes, it is suggested that tomatoes are harvested at 2nd and 3rd week after pollination for long distance transportation and at 4th week for fresh consumption and stored at a temperature of $16^{\circ} \mathrm{C}$.

Keywords: Hardness, Maturity Stages, Pectin-degrading enzymes, Storage temperatures, Tomato fruit
\end{abstract}

ABSTRAK

Saat ini, permintaan akan konsumsi buah tomat setiap hari meningkat pesat. Namun demikian, buah akan mengalami kerusakan mekanis, menyusut, dan melunak saat tahap kematangan, penanganan, dan akibat penyimpanan tidak sesuai dan teksturnya akan terpengaruh. Penelitian ini bertujuan untuk mempelajari profil tekstur dan aktivitas pektinase buah tomat selama tahap kematangan dan suhu penyimpanan serta parameter fisikokimia mereka. Buah dipetik pada 1-4 minggu setelah penyerbukan dan disimpan pada suhu $16^{\circ} \mathrm{C}$ dan $25^{\circ} \mathrm{C}$. Terjadi peningatan warna kemerahan (a*), kadar TSS, susut berat, laju respirasi, dan produksi etilena buah tomat, sedangkan kekerasan, warna terang $\left(\mathrm{L}^{*}\right)$, pH, dan TA menurun sejalan dengan peningkatan tingkat kemasakan (umur petik) dan suhu penyimpanan. Aktivitas enzim Polygalacturonase (PG) dan Pectin methylesterase (PME) yang lebih tinggi ditunjukkan pada suhu $25^{\circ} \mathrm{C}$ daripada suhu $16^{\circ} \mathrm{C}$. Dapat dipastikan bahwa aktivitas pektinase sangat memengaruhi profil tekstur. Untuk tujuan komersial, disarankan untuk menyimpan tomat pada suhu $16^{\circ} \mathrm{C}$ dan panen pada usia minggu ke-2 dan ke-3 setelah penyerbukan untuk transportasi jarak jauh, serta panen pada minggu ke-4 untuk konsumsi segar.

Kata Kunci: Buah tomat, Enzim degradasi pektin, Kekerasan, Suhu penyimpanan, Tahap kematangan

\section{INTRODUCTION}

In the contemporary world, the demand for consumption of fresh agricultural product is increasing along with the increase of the population. In the meantime, postharvest loss of commodities also becomes significant issue. A considerable attempt has been made to prolong the shelf-life of agricultural products. Tomato (Solanum lycopersicum) fruit is one of the globally substantial horticultural products. Nevertheless, it is a climacteric fruit that can be easily exposed to rapid ripening after harvest, thereby extremely restricting storage, transportation, processing, and marketing of the fruit (Xie et al., 2017).
The main factors that can limit the post-harvest life of this fruit are maturity or ripening periods, storage materials, storage conditions (temperature and period), and environmental factors (extreme light and humidity). Maturity triggers the changes in the color, texture, and flavor of tomato fruit (Huang et al., 2018).

Therefore, to attain the desired quality of fruits and vegetables, harvesting or maturity stage is very crucial. Harvesting the fruits at immature stage leads to greater shriveling and mechanical damage, as well as quality loss, while later harvesting causes 
the fruits to be susceptible to overripe, resulting in soft and mealy texture. Identifying the optimal storage temperature is another factor to prolong the fruit's shelf life. A previous study discovered that tomatoes fruits (green) can be stored at 13-16 ${ }^{\circ} \mathrm{C}$ with relative humidity of $85-90 \%$ for an average storage period of 2-6 weeks (Kemper, 2018). Another study confirmed that the ideal ripening stage for red color tomatoes occurs approximately between $18^{\circ} \mathrm{C}$ to $21^{\circ} \mathrm{C}$ (Duma et al., 2017). Maturity stages and storage conditions are the most vital issues to preserve the texture of fruits. Texture change during ripening of fruits is the primary factor that can influence consumer preference, storage, transportation, and shelf life of the produce. The firmness of fruit is a substantial texture attribute that determines the evolution of ripening (Luo, 2007). The investigation by Požrl et al. (2010) revealed that the firmness of tomatoes stored at $5{ }^{\circ} \mathrm{C}$ and $10{ }^{\circ} \mathrm{C}$ diminished from $115.52 \mathrm{~N}$ to $31.83 \mathrm{~N}$ and 19.33 N, respectively. The study by Brackmann et al. (2007) also found a greater decrease in fruit firmness at higher storage temperatures.

Among the organoleptic characteristics, the texture is the considerable major quality parameter of fruits that can determine its commercial and economic importance. The softening during ripening is the process that can diminish fruit quality, which in turn results in economic loss (Paniagua et al., 2014). Ripening is a complicated process, in which several biochemical and physiological alterations of the fruit occur, including the accumulation of pigments, conversion of starch into sugars, aromatic volatiles, and organic acids (Kalamaki et al., 2012). The biochemical changes that occur during ripening are respiration, production of aroma, flavor, and ethylene, and the principal action of cell wall degrading enzymes (Verma et al., 2017). The fruit texture is categorized by principal elements, such as cell-to-cell adhesion and cell-wall thickness and structure, and their modification during ripening (Brummell \& Harpster, 2001). These factors appeared through the increase in activity of pectic cell-wall degrading enzymes, such as Polygalacturonase (PG) and pectin methylesterase (PME) during ripening and softening (Huber et al., 2005). Pectin is one of polysaccharides in plant cell wall, which is structurally and functionally clustered (Kalamaki et al., 2012), complex macromolecules and abundant in galacturonic acid (GalA) (Jolie et al., 2010), and broadly altered through ripening processes (depolymerization, solubilization, and the damage of neutral side chains) (Paniagua et al., 2014).

Fruit texture is mostly applied in arrangement with other maturity indices to identify optimal harvest times to confirm a proper storage capability and acceptable sensory quality by the horticultural industry and consumers. Hence, mechanical characteristics for instance compression and texture profile analysis might be an important quality marker of tomato fruits (Jaren et al., 2012; Tolessa et al., 2018). Accordingly, it is important to provide a better understanding of the maturity stages at harvest and storage conditions of tomato fruit to deliver with desired textural quality to the consumers.

The instruments mostly applied to detect the texture profile of fruits and vegetables are destructive and non-destructive. The Instrumental texture profile analysis (TPA) is the latest destructive method using a double compression test to evaluate the texture attributes of food products (Sañudo-barajas et al., 2019). The benefit of this instrument is that it can quantify several textural parameters of food products objectively and rapidly in only one experiment, and it is strongly associated with sensory evaluation attributes (Rosenthal, 2010). TPA has been applied to determine the texture of numerous fruits and vegetables, such as Date-Tamarind fruit (Zahir et al., 2013), carrot (Sun et al., 2019), 
strawberries (Aday \& Caner, 2013; Caner, Aday, $\&$ Demir, 2008), pomegranate arils and seeds (Szychowski et al., 2015), melon fruit (Bianchi et al., 2016), banana (Chauhan et al., 2006), and tomato (Jaren et al., 2012; Fava et al., 2017). Mostly, these studies are simulations of the instrumental texture profile related to pectinase enzyme activities during the postharvest.

Postharvest problems arise when the fruit is untimely harvested and not appropriately handled during transportation and storage, thereby leading to physical damages, such as mechanical injury and shriveling. These factors principally influence the texture of the fruit as cell-wall is disintegrated due to the cell-wall modifying enzymes progression during maturation and ripening. Tomato variety of Servo F1 is a low and medium land plant with high productivity grown PIAT (Pusat Inovasi Agroteknologi), Universitas Gadjah Mada (UGM), which is susceptible to softening during ripening. Consequently, the postharvest quality of the fruit is limited. To resolve this problem, a precise, scientifically proven information about the maturity stages and storage temperatures of the fruit must be provided. Therefore, the aim of this study was to examine the texture profile and pectinase activity in tomato fruit (Solanum lycopersicum cultivar Servo F1) at different maturity stages and storage temperatures. The physicochemical and postharvest physiology were also examined.

\section{MATERIALS AND METHODS}

\section{Plant Materials}

The samples of tomato fruits (Solanum lycopersicum cultivar Servo F1) were grown at PIAT, UGM's trial field, Yogyakarta, Indonesia during the dry season of 2019 under regular environmental conditions. The fruits were then harvested 1, 2, 3, and 4 weeks after pollination and immediately transported to the laboratory of the Faculty of Agricul- tural Technology, UGM for experimental analysis. Henceforth, the samples of fruits were named as stages $1,2,3$, and 4 for fruits with the age of 1,2 , 3 , and 4 weeks after pollination, respectively.

\section{Storage Conditions}

The sample fruits were selected according to the stage, uniformity of size, color, and shape, then placed in corrugated boxes before stored at a temperature of $16^{\circ} \mathrm{C}$ (cool and dark room) and 25 ${ }^{\circ} \mathrm{C}$ for 9 days. The corrugated box size was 20,25 , and $40 \mathrm{~cm}$. Every 3 days, sampling was done, and the samples were analyzed for their TSS, TA, color, weight loss, respiration rate, ethylene production, texture profile, PG, and PME activity. Three replications were made for each treatment and analysis.

Titratable Acidity (TA), pH, and Total Soluble Solids (TSS)

The clear juice of tomato was prepared for further analysis. Titratable acidity (TA) was measured according to the method of Xin et al. (2010). The $\mathrm{pH}$ of tomato fruit samples was measured using a pH meter (ANNA Instrument Inc.). Total soluble Solid ( ${ }^{\circ}$ Brix) was measured using a hand-held refractometer.

\section{Color Measurement}

Tomato skin surface color values were measured by a Chroma Meter Model CR 400 (Konica Minolta Sensing Inc., Japan) at three equatorial points on the tomato fruit surface. The measurement was based on the CIE color system, in which $\mathrm{L}^{*}$ represents the degree of lightness $\left(\mathrm{L}^{*}=0\right.$ for dark, $L^{*}=100$ for white), $a^{*}$ indicates the intensity of red - green $\left(a^{*}<0\right.$ for green, $a^{*}>0$ for red), and $b^{*}$ stands for the degree in blue - yellow $\left(b^{*}>0\right.$ for yellow, $b^{*}<0$ for blue). Before measurement was done, the chromameter was calibrated with a standard white tile or ceramic plate $\left(L^{*}=93.66 ; a^{*}=-1.46 ; b^{*}=5.24\right)$. Triplicate measurements were done for each sample 
during maturity stages and storage conditions.

Determination of weight loss, respiration rate, and ethylene production

Tomato fruits were weighed using a digital analytical balance at the beginning of the experiment and at each sampling times (0,3,6, and 9 days). Average weight loss was defined as a percentage loss of the initial total weight (PLW), based on equation 1.

$P L W(\%)=$

$\underline{\text { Initial fruit weight-Fruit weight on the day sampling }} 100$ Initial fruit weight

Ethylene production and respiration rate were evaluated according to Chang et al. (2017).

\section{Texture Profile}

The texture profile or hardness was measured using Texture Analyzer (TA1, NEXYGEN plus, AMETEK test, and calibration instruments, Lloyd Instruments Ltd, UK).

Pectic cell-wall analysis: Extraction and fractionation of cell-wall materials

Cell wall materials extraction and fractionation were conducted according to the method by Lu et al. (2016) and Luo (2007), respectively.

\section{Cell-wall modifying enzymes assay}

The enzyme extraction was conducted according to the method by Wei et al. (2010). Polygalacturonase pectin methylesterase (PME) enzymes activity were assayed according to Deng et al. (2005) and Bu et al. (2013) and Hagerman \& Austin (1986), respectively.

\section{Statistical data analysis}

The data were analyzed statistically with ANOVA using SPSS Software version 23. The statistically significant difference among treatments was assessed at $(\mathrm{p} \leq 0.05)$ level of significance using Tukey and Duncan's multiple range tests, and means were compared using the least significant difference (LSD).

\section{RESULTS AND DISCUSSION}

Physicochemical Quality Parameters

Tomato fruits were harvested at different maturity stages and stored at different times and temperatures to distinguish the quality characteristics. The outputs of the experimental analysis of this study are discussed below.

\section{Titratable acidity and $\mathrm{pH}$}

The maturity stages significantly affected titratable acidity of tomato fruit. However, there was no significant effect of storage temperatures and days (Table 1). The results were presented in the percentage of TA in \% citric acid per $g$ of fresh weight (FW). The TA increased in the early stage of maturity and decreased at the end of the stage. During the development of the fruit, there is a synthesis process of all components including acid as a food reserve, which will begin to be broken down at the end of the fruit development process (the beginning of the ripening process). The titratable acidity of tomato fruits decreased during the maturity stages due to the degrading of the citric acid content within the fruit. When pectin breaks down, acidity increases due to the formation of galacturonic acid in the fruit. Conversely, organic acid oxidation reduces acidity as a result of the respiratory process (De Oliveira et al., 2016). The remarkable increase in citric acid concentration at the green-ripe stage and stabilization during ripening was shown in tomato fruits (Gierson \& Kader, 1986). Similarly, in Carissa edulis fruit, due to an increase in $\mathrm{pH}$ and decrease in titratable acidity, maturation and ripening progression were observed (Makumbele et al., 2019).

The results of $\mathrm{pH}$ revealed that there was a statistically significant difference $(\mathrm{p} \leq 0.05)$, varied from 
24 Planta Tropika: Jurnal Agrosains (Journal of Agro Science) Vol. 9 No. 1 / February 2021

Table 1. The physicochemical quality parameters and hardness of tomato fruit at different maturity stages and storage temperatures

\begin{tabular}{|c|c|c|c|c|c|c|c|c|}
\hline \multirow{3}{*}{$\begin{array}{c}\text { Quality } \\
\text { Parameters }\end{array}$} & \multirow{3}{*}{$\begin{array}{c}\text { Maturity } \\
\text { stages }\end{array}$} & \multicolumn{7}{|c|}{ Storage temperature } \\
\hline & & \multicolumn{4}{|c|}{$16^{\circ} \mathrm{C}$} & \multicolumn{3}{|c|}{$25^{\circ} \mathrm{C}$} \\
\hline & & $0 \mathrm{~d}$ & $3 d$ & $6 d$ & $9 d$ & $3 d$ & $6 \mathrm{~d}$ & $9 d$ \\
\hline \multirow{4}{*}{$\begin{array}{l}\text { TA (Citric } \\
\text { acid \%) }\end{array}$} & W1 & $0.47 \pm 0.01^{\text {ca }}$ & $0.54 \pm 0.02^{\text {ca }}$ & $0.49 \pm 0.02^{\mathrm{ca}}$ & $0.52 \pm 0.02^{\mathrm{ca}}$ & $0.47 \pm 0.02^{\text {ca }}$ & $0.53 \pm 0.01^{\text {ca }}$ & $0.55 \pm 0.01^{\text {ca }}$ \\
\hline & W2 & $0.45 \pm 0.02^{\text {aa }}$ & $0.59 \pm 0.00^{\text {aa }}$ & $0.69 \pm 0.01^{\text {aa }}$ & $0.71 \pm 0.03^{\text {aа }}$ & $0.50 \pm 0.00^{\text {aa }}$ & $0.60 \pm 0.00^{\text {aa }}$ & $0.61 \pm 0.01^{\text {aа }}$ \\
\hline & W3 & $0.65 \pm 0.01^{\mathrm{ba}}$ & $0.65 \pm 0.04^{\text {ba }}$ & $0.54 \pm 0.01^{\text {ba }}$ & $0.60 \pm 0.02^{\mathrm{ba}}$ & $0.63 \pm 0.02^{\text {ba }}$ & $0.52 \pm 0.01^{\text {ba }}$ & $0.45 \pm 0.00^{\text {ba }}$ \\
\hline & W4 & $0.56 \pm 0.01^{d a}$ & $0.48 \pm 0.00^{\mathrm{da}}$ & $0.53 \pm 0.01^{\mathrm{da}}$ & $0.46 \pm 0.03^{\mathrm{da}}$ & $0.43 \pm 0.02^{\mathrm{da}}$ & $0.41 \pm 0.00^{\mathrm{da}}$ & $0.42 \pm 0.01^{\mathrm{da}}$ \\
\hline \multirow[t]{4}{*}{$\mathrm{pH}$} & W1 & $4.66^{\mathrm{aa}}$ & $4.42^{\mathrm{ab}}$ & $4.31 \mathrm{ac}$ & $4.29^{\mathrm{ab}}$ & $4.19^{a b}$ & $4.26^{\mathrm{ac}}$ & $4.19^{a b}$ \\
\hline & W2 & $4.46^{\text {ba }}$ & $4.17^{\mathrm{bb}}$ & $4.02 b c$ & $3.95^{\mathrm{bb}}$ & $4.33^{\mathrm{bb}}$ & $4.01^{\mathrm{bc}}$ & $4.01^{\mathrm{bb}}$ \\
\hline & W3 & $3.95^{\text {ba }}$ & $4.07^{\mathrm{bb}}$ & $4.12 b c$ & $4.40^{\mathrm{bb}}$ & $4.05^{\mathrm{bb}}$ & $4.10^{\mathrm{bc}}$ & $4.20^{\mathrm{bb}}$ \\
\hline & W4 & $4.13^{\text {ca }}$ & $4.08^{\mathrm{cb}}$ & $4.08 c c$ & $4.08^{\mathrm{cb}}$ & $4.09^{c b}$ & $4.03^{c c}$ & $4.07^{\mathrm{cb}}$ \\
\hline \multirow[t]{4}{*}{ TSS ('Brix) } & W1 & $4.00 \pm 0.00^{\mathrm{dd}}$ & $4.00 \pm 0.00^{\text {dd }}$ & $4.00 \pm 0.00^{\mathrm{ad}}$ & $4.15 \pm 0.06^{\mathrm{dd}}$ & $4.12 \pm 0.00^{\mathrm{dd}}$ & $4.18 \pm 0.21^{\mathrm{dd}}$ & $4.31 \pm 0.13^{\mathrm{dd}}$ \\
\hline & W2 & $4.00 \pm 0.00^{c c}$ & $4.00 \pm 0.00^{c c}$ & $4.10 \pm 0.00^{b c}$ & $4.20 \pm 0.00^{c c}$ & $4.21 \pm 0.10^{c c}$ & $4.24 \pm 0.00^{c c}$ & $4.37 \pm 0.00^{c c}$ \\
\hline & W3 & $4.00 \pm 0.00^{\mathrm{bb}}$ & $4.20 \pm 0.00^{\mathrm{bb}}$ & $4.20 \pm 0.00^{\mathrm{cb}}$ & $4.35 \pm 0.00^{\mathrm{bb}}$ & $4.20 \pm 0.00^{\mathrm{bb}}$ & $4.40 \pm 0.00^{\mathrm{bb}}$ & $4.50 \pm 0.00^{\mathrm{bb}}$ \\
\hline & W4 & $4.00 \pm 0.00 \mathrm{a}$ & $4.20 \pm 0.00^{\mathrm{aa}}$ & $4.20 \pm 0.00^{c a}$ & $4.90 \pm 0.00^{\mathrm{aa}}$ & $4.60 \pm 0.00^{\text {aa }}$ & $5.10 \pm 0.00^{\text {aa }}$ & $5.40 \pm 0.00^{\text {aa }}$ \\
\hline \multirow{4}{*}{$\begin{array}{l}\text { Hardness } \\
\text { (N) }\end{array}$} & W1 & $399.68 \pm 80.51^{\text {aа }}$ & $365.53 \pm 39.23^{\text {aа }}$ & $343.13 \pm 41.88^{a a}$ & $308.21 \pm 62.50^{\text {aa }}$ & $351.44 \pm 59.53^{\mathrm{aa}}$ & $280.90 \pm 48.59^{\text {aа }}$ & $235.14 \pm 63.29 \mathrm{aa}$ \\
\hline & W2 & $361.60 \pm 65.52^{\text {aа }}$ & $353.53 \pm 39.73^{\text {aа }}$ & $308.84 \pm 46.01^{\text {aa }}$ & $276.56 \pm 77.54^{\text {aa }}$ & $331.32 \pm 57.89^{\text {aa }}$ & $289.17 \pm 79.35^{\text {аa }}$ & $223.88 \pm 34.05^{\mathrm{aa}}$ \\
\hline & W3 & $320.85 \pm 44.77^{\mathrm{bb}}$ & $311.06 \pm 71.53^{\mathrm{bb}}$ & $220.11 \pm 50.71^{\mathrm{bb}}$ & $200.30 \pm 71.74^{b b}$ & $301.45 \pm 39.18^{b b}$ & $212.01 \pm 90.79^{\mathrm{bb}}$ & $191.71 \pm 49.29^{\mathrm{bb}}$ \\
\hline & W4 & $219.32 \pm 59.41^{c c}$ & $214.98 \pm 59.58^{c c}$ & $207.50 \pm 90.34^{c c}$ & $134.09 \pm 38.27^{c c}$ & $164.42 \pm 62.35^{c c}$ & $139.83 \pm 23.87^{c c}$ & $104.21 \pm 24.79^{c c}$ \\
\hline
\end{tabular}

Remarks: Means followed by different letters in the same columns or rows are significantly different $(p \leq 0.05)$. Data are mean \pm standard deviation, $n-3$ for physicochemical parameters, and n-6 for hardness.

4.66 to 4.08 , and 4.07 from the 1 st to 4 th week an increase in soluble solids concentration and a in all storage periods at $16{ }^{\circ} \mathrm{C}$ and $25{ }^{\circ} \mathrm{C}$ storage decrease in titratable acidity is shown in Carissa temperature, respectively (Table 1). The decrease edulis fruit (Makumbele et al., 2019), gooseberry in $\mathrm{pH}$ value might be due to the inhibition of the (Kampuse et al., 2018) and black currants (Ribes enzymatic breakdown of pectin, slowing down nigrum) (Taylor et al., 2013), which are in agreerespiration process, and inhibition of utilization of ment with the current study. This is due to the organic acids and conversion to sugars. The previ- breakdown of carbohydrates into sugars due to the ous study in tomato by Almeida \& Huber (1999) increment of storage period, leading to a decrease fruit supported the current finding, confirming in the $\mathrm{pH}$ of the fruit. The increase in TSS might be that as storage period increased, a decrease in $\mathrm{pH}$ due to the rate conversion of starch to sugar, which from mature-green to fully ripe was observed.

\section{Total soluble solids (TSS)}

The TSS of tomatoes were statistically different, as affected by different maturity stages and storage temperatures. The results showed an increase in total soluble solids along with the increase in maturity stages and storage conditions, ranging from 4 to 4.9 and 5.4 at 16 and $25^{\circ} \mathrm{C}$, respectively (Table 1). During the ripening and maturation process, quality characteristics, and it affects consumer's is higher than the use of sugar as a substrate for respiration. At the end of the maturity stage, as the ripening process and storage conditions extended, a decrease in titratable acidity might happen due to the use of acids other than sugar as substrate for respiration.

\section{Color}

Color is one of the most essential horticultural 
decisions and preferences. There were significant effects of maturation stage and storage temperature on the color (Figure 1). The lightness $\left(\mathrm{L}^{*}\right)$ of tomato fruit was decreasing along with the longer storage periods at all maturity stages and storage temperatures. The highest reduction in lightness was indicated in the 4th harvesting maturity stage at both storage temperatures. In comparison, the lowest drop in lightness was shown in the 1st maturity stage. Meanwhile, the redness $\left(\mathrm{a}^{*}\right)$ of tomato fruits significantly increased at all maturity stages and storage temperatures. The change of the red fruit color $\left(\mathrm{a}^{*}\right)$ was faster at $25^{\circ} \mathrm{C}$ than at $16^{\circ} \mathrm{C}$. The change in fruit color during tomato ripening is due to chlorophyll degradation and carotenoid synthesis (Park et al., 2018). Changes in fruit color from green to red during storage may affect the quality of the tomato fruit because its skin color is associated with maturity stage and a marketable flavor.

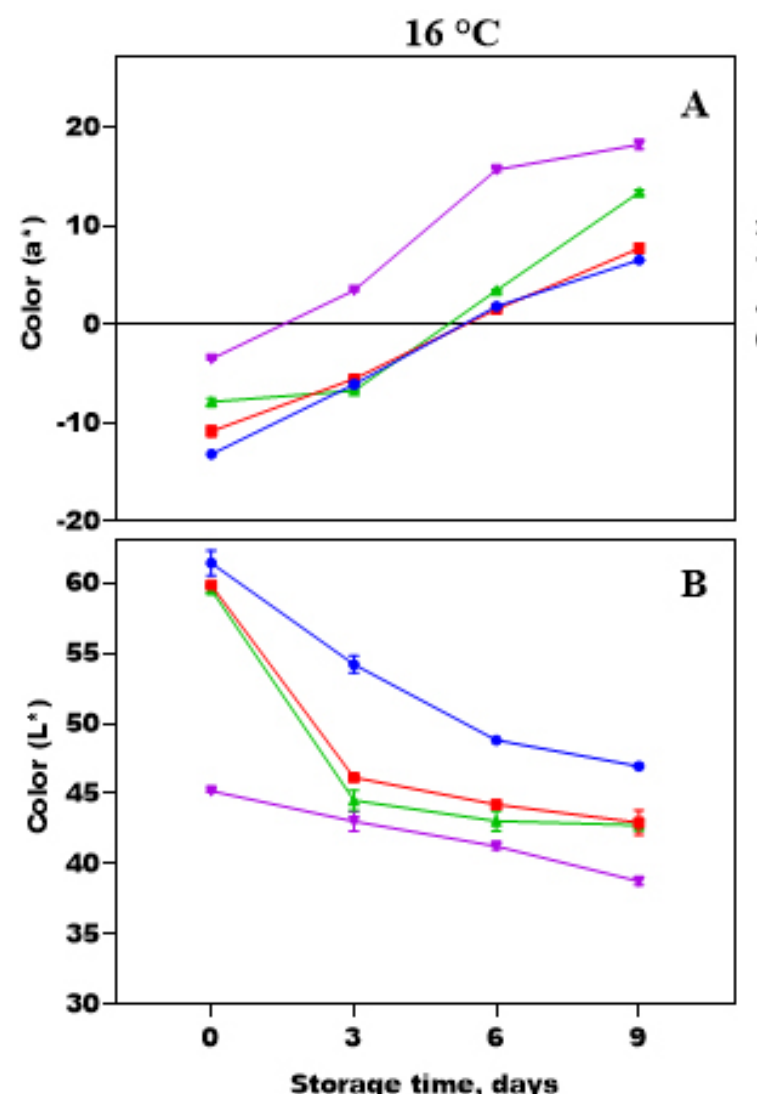

There are several reasons for the degradation of color during storage and ripening of fruits. Color changes in fruits stored at $16^{\circ} \mathrm{C}$ were different than at $25^{\circ} \mathrm{C}$. This is possibly because lycopene, which is the principal cause of the red color in tomato fruit, is not able to be synthesized at a temperature above $25^{\circ} \mathrm{C}$. The ripening process related to the degradation of chlorophyll and the accumulation of pigments (Gierson \& Kader, 1986) have shown that the increase in redness of fruit is a result of the accumulation of lycopene related to an internal membrane system, loss of chlorophyll, increase in soluble pectin resulting from wall softening and degradation, and synthesis of pigments, for example, I-carotene and lycopene. Moreover, Fraser et al. (1994) suggested that the red color of tomato fruit appears after chloroplasts are converted into chromoplasts and as a consequence of chlorophyll degradation and pigment synthesis, namely lyco-

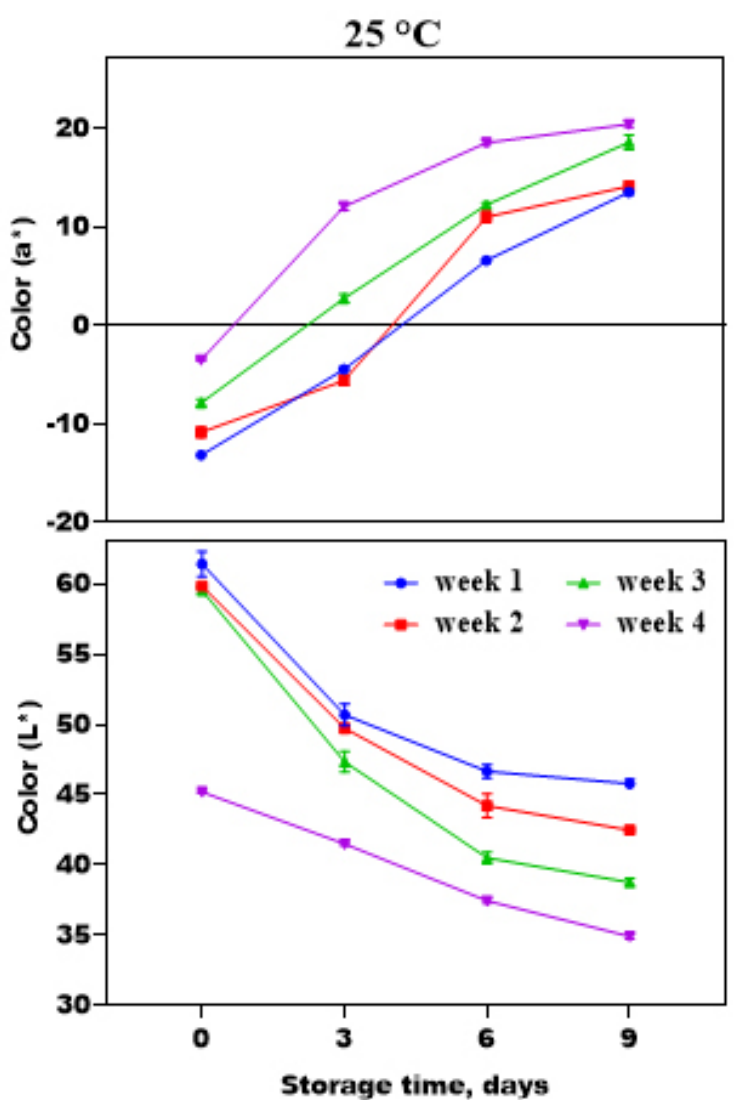

Figure 1. Color changes of tomato fruit at different maturity stages and storage conditions, $(A): a^{*}$ and $(B): L^{*}$. Vertical bars represent standard error $(p \leq 0.05)$ of the means, $n-3$ 
pene and other carotenoids. The previous study by Moneruzzaman et al. (2008) demonstrated a half and full-red color development in tomato fruit on day 9 and 12 storage periods under control condition.

\section{Weight Loss}

The weight loss was significantly different in all treatments (Figure 2a). The highest weight loss was shown at $25^{\circ} \mathrm{C}$ storage temperature. Tomato fruits harvested at the first week of maturity stage at $16^{\circ} \mathrm{C}$ experienced the lowest weight loss during the storage periods $(\mathrm{p} \leq 0.05)$. The highest weight

$16{ }^{\circ} \mathrm{C}$
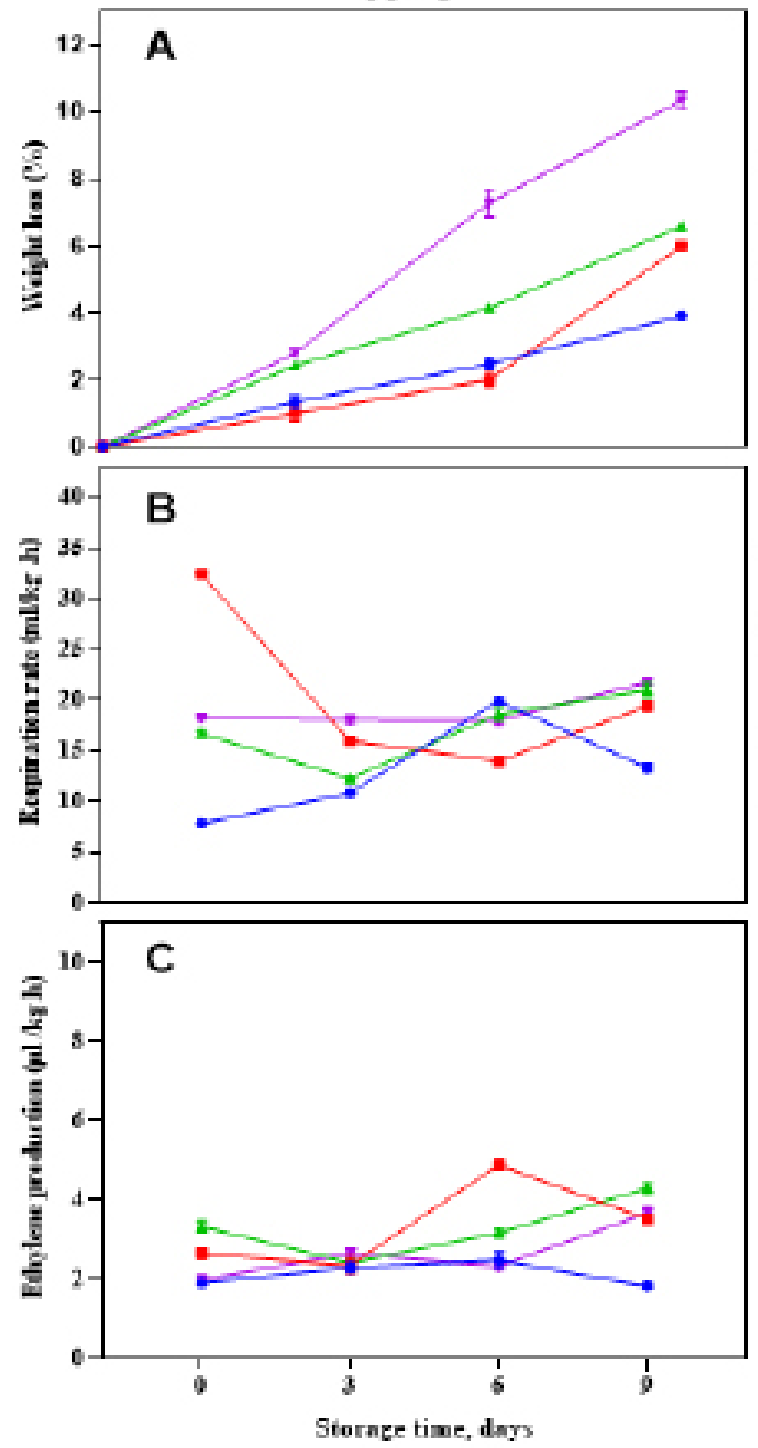

loss percentage was observed in the tomato fruits harvested at the fourth week of the maturity stage, followed by those harvested at the third and second week of maturity stages at $25^{\circ} \mathrm{C}$. Maturity stages and storage conditions (period and temperature) are very influential in increasing the weight loss of the fruit. The tomato fruits stored at a lower temperature showed lower weight loss percentage compared to those stored at a higher storage temperature. The possible cause could be the migration of moisture from the fruit, causing shrinkage of the fruit surface. Javanmardi \& Kubota (2006) revealed that tomato fruits stored at higher temperatures led

$25^{\circ} \mathrm{C}$
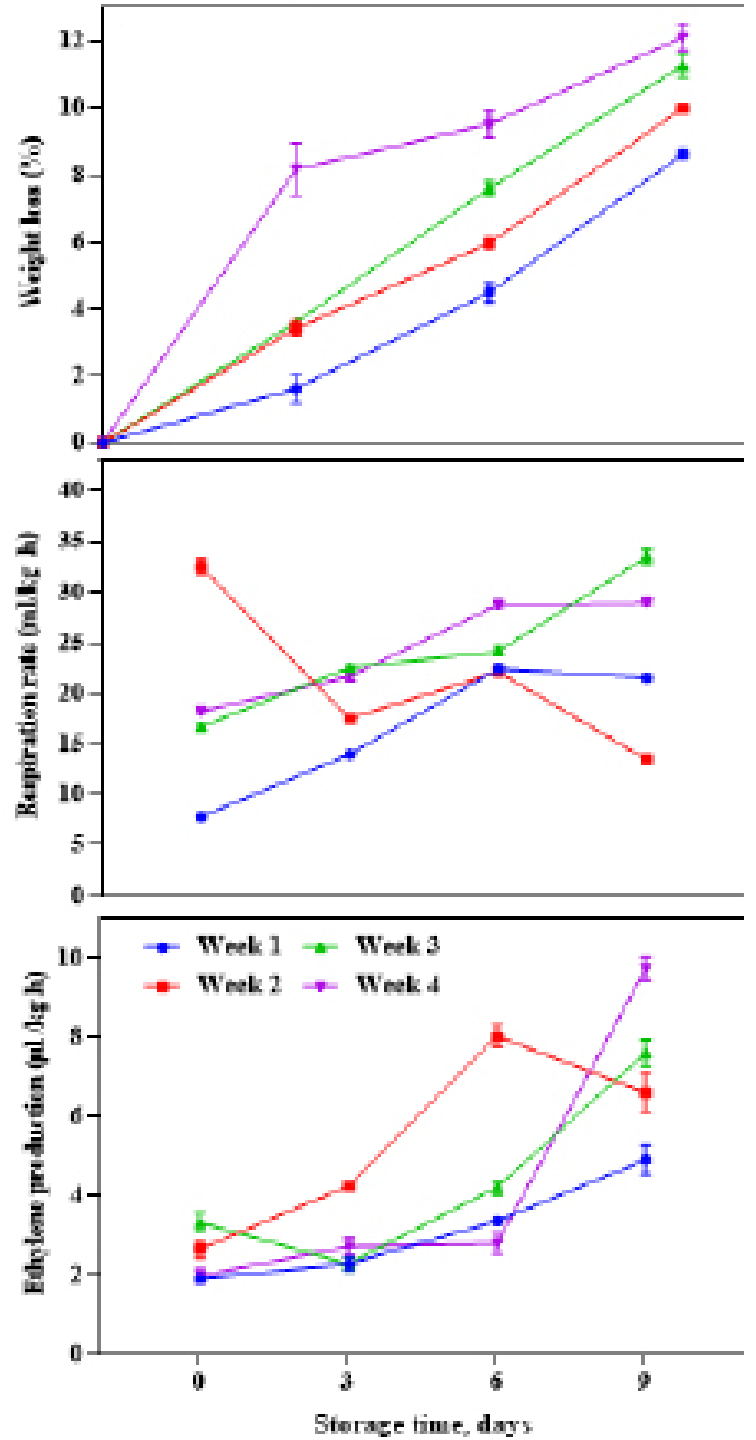

Figure 2. Changes in (A) weight loss $(B)$ respiration rate and $(C)$ ethylene production of tomato fruits during maturity stages and storage temperatures. Bars represent the standard error $(P \leq 0.05)$ of the mean, $n-3$ 
to the highest weight loss percentage due to the advancement of vapor pressure difference (VPD). VPD is the difference between the water vapor pressure in the fruit and the water vapor pressure in the environment. It is suspected that VPD between fruits and the atmosphere plays an important role in reducing fruit weight. An increase in VPD causes less water in the air. VPD at $25^{\circ} \mathrm{C}$ was higher than at $16{ }^{\circ} \mathrm{C}$. Therefore, weight loss at a higher temperature $\left(25^{\circ} \mathrm{C}\right)$ is shown to be greater than at $16^{\circ} \mathrm{C}$. According to Leonardi et al. (2000), higher temperature elevates the variation in vapor pressure among the fruit and its environments. Another study by (Yaman \& Bayoindirli, 2002) confirmed that the moisture loss processes in fruit were due to the difference in water vapor pressure between the fruits and their storage environment, causing vapor phase diffusion. Moreover, moisture content loss from fruits and vegetables is related to cellular membrane disintegration leading to leakages in cellular contents to facilitate senescence (Hailu et al., 2013). This coincidence was demonstrated in several fruits such as snake fruit, in which an escalation in weight loss was higher than $60 \%$ of the total weight of the fruit at the final stage of development (Supriyadi et al., 2002). Less weight loss occurred in the $1 \mathrm{st}, 2 \mathrm{nd}$, and 3 rd weeks at 16 ${ }^{\circ} \mathrm{C}$ during storage periods. In this concept, it is advisable to pick the $1 \mathrm{st}, 2 \mathrm{nd}$, and $3 \mathrm{rd}$ tomatoes and are suitable for storage at a temperature of $16^{\circ} \mathrm{C}$.

\section{Respiration rate}

The progression of $\mathrm{CO}_{2}$ and $\mathrm{C}_{2} \mathrm{H}_{4}$ concentration was measured in a closed system method using an enclosed chamber containing a known weight of tomato fruit inside as a function of time. $\mathrm{CO}_{2}$ gas is one of the physiological parameters of fruits and vegetables, which can determine the quality of the commodities. The output of $\mathrm{CO}_{2}$ gas concentration varies depending on the method of measurement, variety, maturity stages, and storage conditions. Respiration activity is defined as $\mathrm{mL}$ of $\mathrm{CO}_{2} / \mathrm{kg} / \mathrm{h}$. There was significant effect of maturity stages and storage conditions on the production of carbon dioxide ( $\leq \leq 0.05)$ (Figure 2b). Respiration rate dramatically dropped in the $2 \mathrm{nd}$ week of maturation stage at storage temperature of $16^{\circ} \mathrm{C}$ and slightly increased from the $3 \mathrm{rd}$ week. In contrast, the $\mathrm{CO}_{2}$ production in the 2 nd week of maturation stage rapidly diminished through all storage periods at $25^{\circ} \mathrm{C}$, while others increased as the storage time prolonged. Conclusively, respiration rate production revealed an increase in all maturity stages and storage conditions. The development of gas composition in the fruit indicates that the living cells cannot live for long. Tomato fruit is a climacteric fruit with a peak respiration rate through the ripening process. The previous study by Calegario et al. (2001) found that the Santa Clara variety tomato was studied with a continuous flow method, showing an initial increase and decrease in carbon dioxide production as storage period and maturation stages were increased. The result was consistent with the research of Pinheiro et al. (2013) and Ponce-Valadeza et al. (2016). Conclusively, the $\mathrm{CO}_{2}$ concentration was suppressed in all maturity stages at $16^{\circ} \mathrm{C}$ during storage period, while the production was higher at $25^{\circ} \mathrm{C}$ during all maturity stages and days. Therefore, this suggests that for picking tomatoes at the 1st to 4th week after pollination and it is advisable to keep them at a temperature of $16^{\circ} \mathrm{C}$.

\section{Ethylene production}

Ethylene gas production is the main postharvest physiological factor that facilitates the softening of the fruit softening due to cell wall breakdown enzymes generated by ethylene responsive genes. Ethylene production during maturity stages and storage conditions was significantly different at $p$ 
$\leq 0.05$ (Figure 2c). The ethylene production drastically increased at $25^{\circ} \mathrm{C}$ in all storage periods. In contrast, ethylene production content was the lowest at $16{ }^{\circ} \mathrm{C}$ in all maturity stages and storage periods. A peak at $16^{\circ} \mathrm{C}$ was seen in 6 days and decreased at 9 days. Meanwhile, a peak at $25^{\circ} \mathrm{C}$ was shown in the 4th week of maturity stage at 9 days, followed by the 4th week maturity stage at 6 days. In the case of storage temperature, the highest peak of ethylene production was observed at $25^{\circ} \mathrm{C}$ when compared to $16^{\circ} \mathrm{C}$. In other cases, the ethylene gas production in the 1 st, $2 \mathrm{nd}, 3 \mathrm{rd}$, and 4th week of maturity stage over storage conditions. From the result, the cell-wall modifying enzymes that accelerate the ethylene production of fruit was suppressed and inhibited at the $16^{\circ} \mathrm{C}$ during storage periods in comparison to $25^{\circ} \mathrm{C}$. In climacteric fruits such as tomato fruits, the ripening and softening start due to the transient burst of ethylene production and increase in respiration rate. Ethylene is a hormone regulating the expression of ripening correlated genes, coordinates, and regulates the whole ripening process (Brummell \& Harpster, 2001). As reported by We et al. (2018), the enzymes responsible the production of ethylene biosynthesis were much higher at $25^{\circ} \mathrm{C}$ than at 4 ${ }^{\circ} \mathrm{C}$. Therefore, this study concluded that the ethylene concentration of the fruit was suppressed at all maturity stages at $16^{\circ} \mathrm{C}$, whereas it was higher at 25 ${ }^{\circ} \mathrm{C}$ at all maturity stages. Therefore, it is advisable to harvest tomatoes from the 1 st to 4 th week after pollination and should be kept at $16^{\circ} \mathrm{C}$.

\section{Texture profile}

The texture is a vital attribute to ascertain the quality characteristic and post-harvest life of fruits. The hardness (firmness) can be defined as a force required to achieve a provided deformation, and it is the first compression or maximum force in the TPA first cycle. The texture analyzer was equipped with a $1 \mathrm{kN}$ load cell and a $35 \mathrm{~mm}$ diameter cylinder plunger (probe). The tomatoes were left and compressed with a test speed of $1 \mathrm{~mm} / \mathrm{s}$ and a waiting time of 5 seconds between two cycles. Mesocarp tissue samples were compressed $70 \%$ of their original height with a cylindrical probe with a crosshead speed of $52 \mathrm{~mm}$ min-1. Finally, the maximum force is defined as Newton $(\mathrm{N})$. Hardness analysis was performed using Texture Exponent Software equipped with a texture analyzer.

There was significant effect of the maturity stages and storage temperatures on the hardness of tomato fruit (Table 1). The highest decrease in hardness was shown at 4th, while the lowest decrease was shown at 1st, $2 \mathrm{nd}$, and $3 \mathrm{rd}$ week, respectively, during both storage temperature. There was a huge difference between the 1st, 3rd, and 4th week and the $2 \mathrm{nd}, 3 \mathrm{rd}$, and 4 th week of maturity stages in all storage temperatures. However, no significant difference was seen between the 1 st and 2 nd at both storage temperatures. The lowest hardness values occurred on day 9 for all stages of maturity and storage temperatures, followed by days 6,3 , and 0 . Hardness was strongly influenced at $25^{\circ} \mathrm{C}$, while hardness was expressed at $16^{\circ} \mathrm{C}$. Conclusively, a significant reduction in fruit hardness was shown during all maturity stages and storage temperatures.

Texture or hardness depends on the tomato varieties or cultivar, environmental factors such as temperature and humidity, and maturity stages. Fruit texture determines the alterations in the cohesion of the pectin gel results in the hydration of the cell-wall structure and makes the cells separate easily from one another (Jarvis, 1984). The process of ripe fruit softening occurs due to the loss of cohesion in pectin gel (Jarvis, 1984). Maturity stages and storage temperatures sharply affected the hardness of tomatoes. The study is in agreement with Aday \& Caner (2013); Aday, Caner, \& Rahvalı (2011); Caner et al. (2008), 
showing a sharp reduction in hardness observed in strawberries during. Moreover, the current study is in agreement with Guiné (2013) in the sense that an increase in maturity stages and storage temperatures extremely diminished the hardness of pears. The possible reason for the reduction in hardness is supported by Moreno et al. (2012), stating that the highest temperature facilitates the respiration rate and results in damaged middle lamella, collapsed cell wall, water loss, and conversion of sugar to starch. Loss of fruit firmness is triggered by dissolving the middle lamellae, leading to decreased adhesion between cells, depolymerization, and polymerization of hemicellulose and pectic cell wall polysaccharides, especially wall swelling (Brummell $\&$ Harpster, 2001). A similar pattern of firmness changes was seen with the correlation of increased PG enzyme activity and loss of firmness in different mango fruit cultivars during ripening (Abu-Sarra \& Abu-Goukh, 1992).

\section{Pectin cell-wall fractions content}

This study only discusses the content of the water-soluble pectin (WSP) fraction. The results illustrated that WSP increased with the increase in maturity stage and storage temperature (Table 2) Nevertheless, the WSP content of the tomato fruits at $16{ }^{\circ} \mathrm{C}$ was much lower than that at $25^{\circ} \mathrm{C}$ in all maturity stages and storage periods $(\mathrm{p} \leq 0.05)$. The highest water-soluble pectin content was shown at the 2 nd maturity stage, the 9 th day at a temperature of $25^{\circ} \mathrm{C}$, while the lowest was presented at the 1 st maturity stage at 0 days. The results have shown that water-soluble pectin fraction content of tomato fruit increased during its development. However, it shows a decreasing trend at the 4th week of the maturity stage at both storage temperatures. A similar study on tomato fruit confirm that pectin is a water-insoluble protopectin in immature fruit, which is then converted into water-soluble pectin during the development of ripening (Inari et al., 2002). Increased solubility of the fruit leads to the breakup of cell-wall substances. This mechanism occurs mainly due to PME enzyme activity that catalyzes the methylation of methyl esters of polygalacturonic acid, thereby reducing the molecular weight of the fruit, and the texture becomes soft as the pectin depolymerized into a water-soluble fraction. A study by Inari et al. (2002) proved that the higher methoxy pectin content was converted into less methoxy content as the fruit fully ripens. In peaches, a maximum increase in the neutral sugar composition is shown during the developmental stage and an increase in ripening (Brummell et al., 2004). Similarly, in snake fruit, massive a large increase in the major reducing sugar levels of methyl esters was observed during the ripening process (Supriyadi et al., 2002). In rabbiteye blueberry, the WSP content was higher during maturation (Deng et al., 2014), the possible reason could be that covalently bound pectin is released, and the fruit becomes soluble. A previous study by Cámara

Table 2. The pectin content of cell-wall fraction $(\mathrm{mg} / \mathrm{g} \mathrm{CW}$ ) of tomato fruits at different maturity stages and storage temperatures

\begin{tabular}{|c|c|c|c|c|c|c|c|c|}
\hline \multirow{3}{*}{$\begin{array}{l}\text { Pectin } \\
\text { fraction }\end{array}$} & \multirow{3}{*}{$\begin{array}{l}\text { Maturity } \\
\text { stages }\end{array}$} & \multicolumn{7}{|c|}{ Storage temperatures } \\
\hline & & \multicolumn{4}{|c|}{$16^{\circ} \mathrm{C}$} & \multicolumn{3}{|c|}{$25^{\circ} \mathrm{C}$} \\
\hline & & $0 \mathrm{~d}$ & $3 d$ & $6 \mathrm{~d}$ & $9 d$ & $3 d$ & $6 \mathrm{~d}$ & $9 \mathrm{~d}$ \\
\hline \multirow{4}{*}{ WSP } & W1 & $126.8^{a}$ & $130.6^{\text {aa }}$ & $145.6^{\text {aaa }}$ & $207^{\text {ae }}$ & $148.8^{f f}$ & $183.2^{i}$ & $210.8^{\mathrm{ii}}$ \\
\hline & W2 & $132.8^{b}$ & $151.6^{\mathrm{bb}}$ & $165.2^{\mathrm{bbb}}$ & $226^{b f}$ & $142.6^{\mathrm{ee}}$ & $188.8^{j}$ & $355.6^{\mathrm{mm}}$ \\
\hline & W3 & $282.2^{d}$ & $236.6^{\mathrm{dd}}$ & $230.8^{d d d}$ & $244.8^{\mathrm{cg}}$ & $209.6^{\text {hh }}$ & $236.6^{\mathrm{m}}$ & $258.4^{\mathrm{ji}}$ \\
\hline & W4 & $246.4^{c}$ & $205.8^{\mathrm{cc}}$ & $216^{\mathrm{ccc}}$ & $246.8^{\mathrm{dh}}$ & $200.4^{g g}$ & $221.6^{k}$ & $271.4^{\mathrm{kk}}$ \\
\hline
\end{tabular}

Remarks: Means followed by different letters in the same columns or rows are significantly different $(p \leq 0.05)$. 
Hurtado et al. (2002) confirmed that the dissolving and depolymerization processes increased the water-soluble pectin content and reduced ionic, covalent bonding substances during ripening. These results confirm that there is a negative relationship between WSP hardness and content in all maturation stages and storage conditions. However, the correlation was positive at the 4th week at both storage temperatures.

\section{Cell-wall modifying enzymes activity}

The Polygalacturonase enzyme activity was determined by measuring the absorbance of reducing groups. The absorbance of reducing groups was measured at $540 \mathrm{~nm}$ with D-galacturonic acid (Sigma, Aldrich) as a standard. One unit of enzyme is the amount that catalyzes the formation of $1 \mu$ mole of reducing groups per min per $g$ fresh

$16{ }^{\circ} \mathrm{C}$
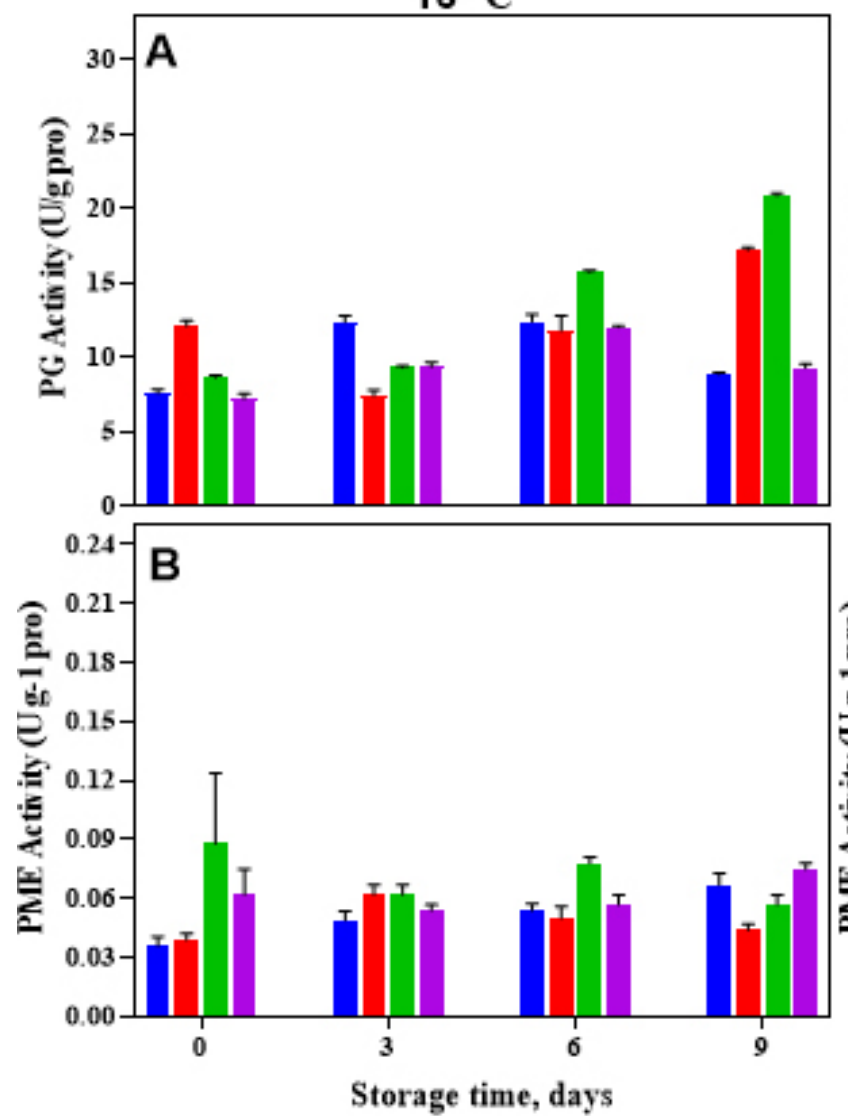

weight of tomato fruit. There was significant effect of the maturity stages and storage temperatures on the Polygalacturonase enzyme activity at $p \leq 0.05$ as can be seen in Figure 3a. However, there was no significant difference between the 1 st and 2 nd week of the maturity stage. The tremendous increase in the PG enzyme activity was illustrated at the 3rd week of the maturity stage, while the lowest value was shown at the 4th week of the maturity stages at both storage temperatures. The PG activity increased at the 1 st and 4th weeks from 0 to 6 days, and declined at the 9th day of the storage period at $16{ }^{\circ} \mathrm{C}$. In contrast, there was a dramatic increase shown at the $2 \mathrm{nd}$ and $3 \mathrm{rd}$ week of the maturity stage in all storage periods at $16{ }^{\circ} \mathrm{C}$. In comparison, an increasing tendency was shown in all maturity stages and storage periofs at $25^{\circ} \mathrm{C}$. The highest PG activity was observed at the 1 st week

$25^{\circ} \mathrm{C}$

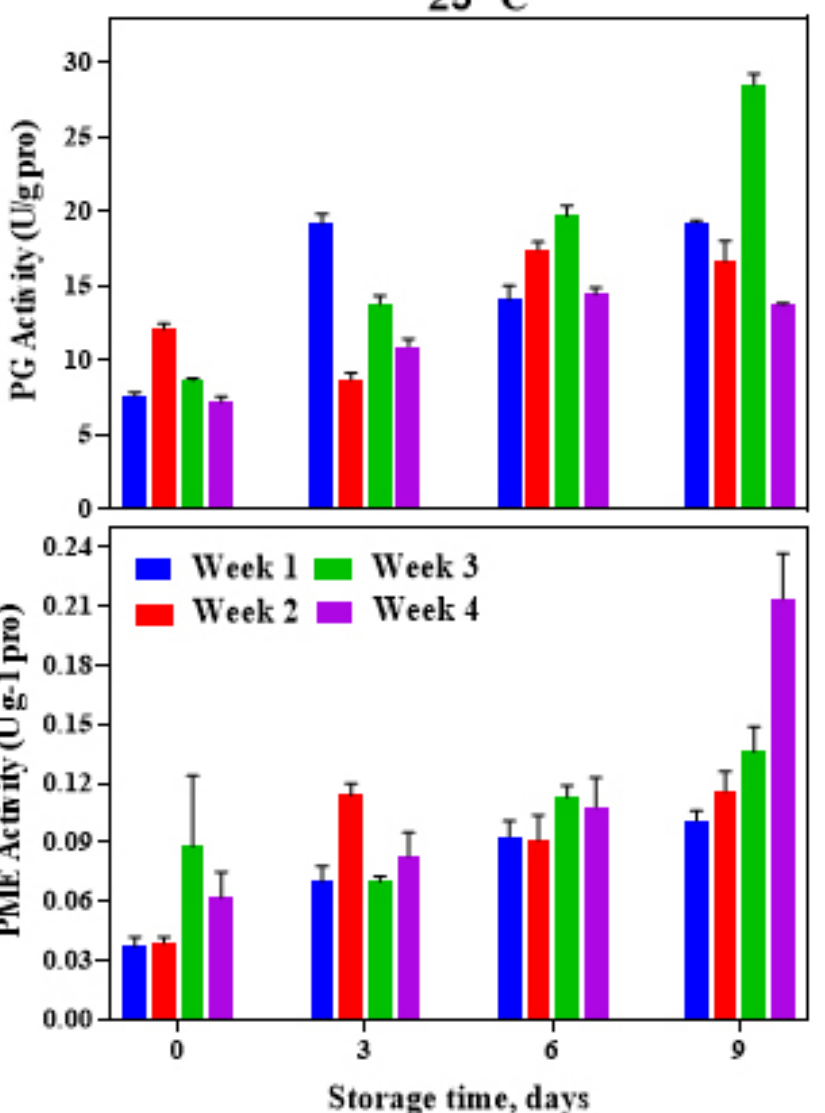

Figure 3. PG (A) and PME (B) enzymes activity ( $\mathrm{U}^{-1} \mathrm{~g}^{-1}$ protein) on tomato fruit at different maturity stages and storage temperatures. Vertical bars represent standard error $(p \leq 0.05)$ of mean, $n-3$ 
of the maturity stage on day 3 , and it dropped on day 6 at $25^{\circ} \mathrm{C}$. The maximum peak of PG activity was found at the $3 \mathrm{rd}$ week of the maturity stage of day 9 at $25^{\circ} \mathrm{C}$. It was supposed that the $3 \mathrm{rd}$ week of the maturity stage was the period of maximum fruit development before entering the fruit ripening period, marked by a color change to yellow-red. A remarkable decline was shown at the 4th week of the maturity stage at both storage temperatures. In general, the lowest $\mathrm{PG}$ enzyme activity occurred at $16^{\circ} \mathrm{C}$, while the highest at $25^{\circ} \mathrm{C}$. The same increasing trend in $\mathrm{PG}$ activity was shown in apples during storage after harvest (Wei et al., 2010). A similar pattern was shown in Pawpaw fruit during ripening, in which the PG activity tended to increase gradually until a certain stage and later declined at the late maturity stage (Koslanund et al., 2005).

The activity of the PME enzyme is expressed as unit per gram of protein ( $\mathrm{U} g-1 \mathrm{pr})$. The activity of one unit of enzyme is the same as $1 \mu \mathrm{mol}$ galacturonic acid per minute. PME activity was estimated from a standard curve constructed using galacturonic acid as a standard.

There was a significant effect of the maturity stages and storage temperatures on the PME activity. highest PME activity was observed at the 4th week of the maturity stage on day 9 at $25^{\circ} \mathrm{C}$, as demonstrated in Figure 3b. There was a significant difference in PME between the 1st, 3rd, and 4th week of the maturity stage. The peak of the increase in PME activity was observed at $25^{\circ} \mathrm{C}$ with the increase in storage period and maturity stage. A storage temperature of $25^{\circ} \mathrm{C}$ triggered the increase in PME activity in all maturity stages and storage periods, while a storage temperature of $16^{\circ} \mathrm{C}$ suppressed the PME activity and maintained shelf life of tomato fruit. There is no huge gap between the treatments in the PME activity at $16^{\circ} \mathrm{C}$ in all maturity stages and storage periods. An exponential increase in PME activity was observed during ripen- ing or maturation of pear fruit (Nagel \& Patterson, 1967) and banana fruit (Patil and Magar, 1975). The current study also showed exponential increase in PME activity in tomatoes in later maturation stage and higher storage temperature. This is a critical indication that temperature and environmental factors enormously accelerate the enzymatic activity in the fruit during storage. Moreover, extending the harvesting at later maturity stage is a key factor that can speed up the enzyme activity, which results in soft texture and poor quality as well as short shelflife of the fruit.

The disintegration of pectin cell wall composition is principally caused by the activity of cell wall modifying enzymes (Brummell \& Harpster, 2001). The vital enzymes responsible for cell-wall disintegration are PG, PME, and Cellulase (Brummell \& Harpster, 2001; Li et al., 2010). However, the current work focused on PG and PME enzymes. PG is the enzyme involved in pectin solubilization by catalyzing the hydrolytic cleavage of galacturonide linkages (Brummell \& Harpster, 2001; Li et al., 2010), and it facilitates pectin solubilization and depolymerization of tomato fruit during ripening (Watson et al., 1994). The higher storage temperature in combination with the storage periods and maturity stages at harvest triggers and enhances the dramatic increase in PG activity in the fruit. This study is supported by Bu et al. (2013) in the sense that a rapid increase in $\mathrm{PG}$ activity was indicated by tomatoes stored at $18^{\circ} \mathrm{C}$ and $25^{\circ} \mathrm{C}$ during storage period, thus $\mathrm{PG}$ promoted fruit softening in the initial or later stages. A similar study implied that PG could play a great role in the mid and late periods of storage (Wei et al., 2010). During the ripening of fruits, the main chain of polygalacturonic acid is catalyzed by PG (Wei et al., 2015). The study is also in agreement with Sheehy et al. (1988), reporting that a huge rise in PG activity through ripening phases is a result of the increase in enzyme molecules. For this reason, when the 
integrity of the middle lamella is influenced by PG activity, then the texture of the fruit will be affected (Wei et al., 2010). The previous finding demonstrated that an increase in PG activity was correlated with the massive dissolution of the cell wall of the fruit (Crookes \& Grierson, 1983). Similarly, in snake fruit, a tremendous rise in PME was observed through maturity stages (Supriyadi et al., 2003). An increase in PME strongly influences the hardness of tomato fruit to a less extent along with the increased storage temperatures and later maturity stages.

\section{CONCLUSION}

In conclusion, the later maturity stages and higher storage temperatures significantly affected the quality parameters, especially at $25^{\circ} \mathrm{C}$. Changes in hardness was related to the increasing watersoluble pectin and the activity of PG and PME enzymes. For commercial purposes, it is recommended to store tomatoes at $16^{\circ} \mathrm{C}$. Harvesting tomatoes at the maturity stage of the $2 \mathrm{nd}$ and 3 rd week after pollination is recommended for long-distance transport, while harvesting at 4th week after pollination is recommended for fresh consumption.

\section{ACKNOWLEDGMENT}

The author would like to thank the financial support from PIAT (Pusat Inovasi Agroteknologi), Universitas Gadjah Mada.

\section{REFERENCES}

Abu-Sarra, A. F., \& Abu-Goukh, A. A. (1992). Changes in pectinesterase, polygalacturonase and cellulase activity during mango fruit ripening. Journal of Horticultural Science, 67(4), 561-568. https://doi.org/10.1080/00221589.1992.11516284

Aday, M. S., \& Caner, C. (2013). LWT - Food Science and Technology The shelf life extension of fresh strawberries using an oxygen absorber in the biobased package. LWT - Food Science and Technology, 52(2), 102-109. https://doi.org/10.1016/j. Iwt.2012.06.006

Aday, M. S., Caner, C., \& Rahvalı, F. (2011). Postharvest Biology and Technology Effect of oxygen and carbon dioxide absorbers on strawberry quality. Postharvest Biology and Technology, 62(2), 179-187. https://doi.org/10.1016/j.postharvbio.2011.05.002 Almeida, D. P. F., \& Huber, D. J. (1999). Apoplastic pH and inorganic ion levels in tomato fruit: A potential means for regulation of cell wall metabolism during ripening. Physiologia Plantarum, 105(3), 506-512. https://doi.org/10.1034/j.13993054.1999.105316.x

Bianchi, T., Guerrero, L., Gratacós-Cubarsí, M., Claret, A., Argyris, J., Garcia-Mas, J., \& Hortós, M. (2016). Textural properties of different melon (Cucumis melo L.) fruit types: Sensory and physicalchemical evaluation. Scientia Horticulturae, 201, 46-56. https:// doi.org/10.1016/j.scienta.2016.01.028

Brackmann, A., Steffens, C. A., Andriolo, J. L., \& Pinto, J. A. V. (2007). Armazenamento de tomate cultivar "Cronus" em função do estádio de maturação e da temperatura. Ciência Rural, 37(5), 1295-1300. https://doi.org/10.1590/s010384782007000500012

Brummell, D. A., Dal Cin, V., Crisosto, C. H., \& Labavitch, J. M. (2004). Cell wall metabolism during maturation, ripening and senescence of peach fruit. Journal of Experimental Botany, 55(405), 2029-2039. https://doi.org/10.1093/jxb/erh227

Brummell, D. A., \& Harpster, M. H. (2001). Cell wall metabolism in fruit softening and quality and its manipulation in transgenic plants. Plant Molecular Biology, 47(1-2), 311-340. https://doi. org/10.1023/A:1010656104304

Bu, J., Yu, Y., Aisikaer, G., \& Ying, T. (2013). Postharvest UV-C irradiation inhibits the production of ethylene and the activity of cell wall-degrading enzymes during softening of tomato (Lycopersicon esculentum L.) fruit. Postharvest Biology and Technology, 86, 337-345. https://doi.org/10.1016/j.postharvbio.2013.07.026

Calegario, F. F., Cosso, R. G., Almeida, F. V., Vercesi, A. E., \& Jardim, W. F. (2001). Determination of the respiration rate of tomato fruit using flow analysis. Postharvest Biology and Technology, 22(3), 249-256. https://doi.org/10.1016/S0925-5214(01)00096-5

Cámara Hurtado, M., Greve, L. C., \& Labavitch, J. M. (2002). Changes in cell wall pectins accompanying tomato (Lycopersicon esculentum Mill.) paste manufacture. Journal of Agricultural and Food Chemistry, 50(2), 273-278. https://doi.org/10.1021/ jf010849e

Caner, C., Aday, M. S., \& Demir, M. (2008). Extending the quality of fresh strawberries by equilibrium modified atmosphere packaging. European Food Research and Technology, 227(6), 1575-1583. https://doi.org/10.1007/s00217-008-0881-3

Chang, E.-H. H., Lee, J.-S. S., \& Kim, J.-G. G. (2017). Cell wall degrading enzymes activity is altered by high carbon dioxide treatment in postharvest 'Mihong' peach fruit. Scientia Horticulturae, 225(March), 399-407. https://doi.org/10.1016/j. scienta.2017.07.038

Cocaliadis, M. F., Fernández-Muñoz, R., Pons, C., Orzaez, D., \& Granell, A. 2010. Increasing tomato fruit quality by enhancing fruit chloroplast function: A review. Journal of Experimental Botany, 65 (16): 4589-4598. doi:10.1093/jxb/eru165.

Crookes, P. R., \& Grierson, D. (1983). Ultrastructure of Tomato Fruit Ripening and the Role of Polygalacturonase Isoenzymes in Cell Wall Degradation. Plant Physiology, 72(4), 1088-1093. https:// doi.org/10.1104/pp.72.4.1088 
D. L. PATIL AND N. G. MAGAR. (1975). Correlation between banana fruits ripening, its texture and pectin-methyl esterase activity. Proc. Indian Acad. Sol., 81(3), 127-130.

De Oliveira, C. M., Ferreira, L. M., Do Carmo, M. G. F., \& Coneglian, R. C. C. (2016). Influence of maturity stage on fruit longevity of cherry tomatoes stored at ambient and controlled temperature. Semina:Ciencias Agrarias, 37(6), 4027-4038. https://doi. org/10.5433/1679-0359.2016v37n6p4027

Deng, J., Shi, Z., Li, X., \& Liu, H. (2014). Effects of cold storage and 1 -methylcyclopropene treatments on ripening and cell wall degrading in rabbiteye blueberry (Vaccinium ashei) fruit. Food Science and Technology International, 20(4), 287-298. https:// doi.org/10.1177/1082013213483611

Deng, Y., Wu, Y., \& Li, Y. (2005). Changes in firmness, cell wall composition and cell wall hydrolases of grapes stored in high oxygen atmospheres. Food Research International, 38(7), 769-776. https://doi.org/10.1016/j.foodres.2005.03.003

aDuma, M., Alsina, l., Dubova, L., \& Erdberga, I. (2017). Quality of tomatoes during storage. 130-133. https://doi.org/10.22616/ foodbalt.2017.030

Fava,J., Nieto, A., Hodara, Alzamora, S.M., \& Castro, M. A. (2017). A Study on Structure (Micro, Ultra, Nano), Mechanical, and Color Changes of Solanum Iycopersicum L. (Cherry Tomato) Fruits Induced by Hydrogen Peroxide and Ultrasound. Food and Bioprocess Technology, 10(7), 1324-1336. http://doi. org/10.1007/s11947-017-1905-4

Fraser, P. D., Truesdale, M. R., Bird, C. R., Schuch, W., \& Bramley, P. M. (1994). Carotenoid biosynthesis during tomato fruit development. Evidence for tissue-specific gene expression. Plant Physiology, 105(1), 405-413. https://doi.org/10.1104/ pp.105.1.405

Gierson, D., \& Kader, A. A. (1986). Fruit ripening and quality. The Tomato Crop, 241-280. https://doi.org/10.1007/978-94-0093137-4_6

Guiné, R. P. F. (2013). Variation of textural attributes of S. Bartolomeu pears at maturation, storage, and drying. International Journal of Food Properties, 16(1), 180-192. https://doi.org/10 $.1080 / 10942912.2010 .535191$

Hagerman, A. E., \& Austin, P. J. (1986). Continuous Spectrophotometric Assay for Plant Pectin Methyl Esterase. Journal of Agricultural and Food Chemistry, 34(3), 440-444. https://doi. org/10.1021/jf00069a015

Hailu, M., Workneh, T. S., \& Belew, D. (2013). Review on postharvest technology of banana fruit. African Journal of Biotechnology, 12(7), 635-647. https://doi.org/10.5897/AJBX12.020

Huang, Y., Lu, R., \& Chen, K. (2018). Assessment of tomato soluble solids content and $\mathrm{pH}$ by spatially-resolved and conventional Vis/NIR spectroscopy. Journal of Food Engineering, 236(May), 19-28. https://doi.org/10.1016/j.jfoodeng.2018.05.008

HUBER, D. J., KARAKURT, Y., \& JEONG, J. (2005). Pectin degradation in ripening and wounded fruits. Revista Brasileira de Fisiologia Vegetal, 13(2), 224-241. https://doi.org/10.1590/s010331312001000200009

Inari, T., Yamauchi, R., Kato, K., \& Takeuchi, T. (2002). Changes in Pectic Polysaccharides during the Ripening of Cherry Tomato Fruits. Food Science and Technology Research, 8(1), 55-58. https://doi.org/10.3136/fstr.8.55

Jaren, C., Arazuri, S., Arana , I., Arias, N., Riga, P., \& Epalza, B.
(2012). Detection of mealiness in tomatoes by textural analysis. Acta Horticulturae, 934 (934), 1135-1140. https:// doi.org/10.17660/ActaHortic.2012.934.152

Jarvis, M. C. (1984). Structure and properties of pectin gels in plant cell walls. Plant, Cell \& Environment, 7(3), 153-164. https://doi. org/10.1111/1365-3040.ep11614586

Javanmardi, J., \& Kubota, C. (2006). Variation of Iycopene, antioxidant activity, total soluble solids and weight loss of tomato during postharvest storage. Postharvest Biology and Technology, 41(2), 151-155. https://doi.org/10.1016/j.postharvbio.2006.03.008

Jolie, R. P., Duvetter, T., Van Loey, A. M., \& Hendrickx, M. E. (2010). Pectin methylesterase and its proteinaceous inhibitor: A review. Carbohydrate Research, 345(18), 2583-2595. https://doi. org/10.1016/j.carres.2010.10.002

Kalamaki, M. S., Stoforos, N. G., \& Taoukis, P. S. (2012). Pectic Enzymes in Tomatoes. Food Biochemistry and Food Processing: Second Edition, (November), 232-246. https://doi. org/10.1002/9781118308035.ch12

Kampuse, S., Kruma, Z., Dorofejeva, K., Ungure, E., \& Kampuss, K. (2018). The comparison of gooseberry biochemical composition in different ripening stages. Acta Horticulturae, 1209, 157-163. https://doi.org/10.17660/ActaHortic.2018.1209.23

Kemper, W. (2018). Storage of Fruits and Vegetables. Retrieved from www.gardeninghelp.org

Koslanund, R., Archbold, D. D., \& Pomper, K. W. (2005). Pawpaw [Asimina triloba (L.) Dunal] fruit ripening. Il. Activity of selected cell-wall degrading enzymes. Journal of the American Society for Horticultural Science, 130(4), 643-648. https:// doi.org/10.21273/jashs.130.4.643

Leonardi, C., Guichard, S., \& Bertin, N. (2000). High vapour pressure deficit influences growth, transpiration and quality of tomato fruits. Scientia Horticulturae, 84(3-4), 285-296. https://doi. org/10.1016/S0304-4238(99)00127-2

Li, X., Xu, C., Korban, S. S., \& Chen, K. (2010). Regulatory mechanisms of textural changes in ripening fruits. Critical Reviews in Plant Sciences, 29(4), 222-243. https://doi.org/10.1080/0735268 9.2010 .487776

Lu, H., Li, L., Limwachiranon, J., Xie, J., \& Luo, Z. (2016). Effect of UV-C on ripening of tomato fruits in response to wound. Scientia Horticulturae, 213, 104-109. https://doi.org/10.1016/j. scienta.2016.10.017

Luo, Z. (2007). Effect of 1-methylcyclopropene on ripening of postharvest persimmon (Diospyros kaki L.) fruit. LWT - Food Science and Technology, 40(2), 285-291. https://doi.org/10.1016/j. Iwt.2005.10.010

Makumbele, F. P., Taylor, M., Stander, M., Anyasi, T. A., Jideani, A. I. 0., \& Carissa, F. (2019). Harvested at Ripe Stage of Maturation. 24(2630). https://doi.org/10.3390/molecules24142630

Moneruzzaman, K. M., Hossain, A. B. M. S., Sani, W., \& Saifuddin, M. (2008). Effect of stages of maturity and ripening conditions on the physical characteristics of tomato. American Journal of Biochemistry and Biotechnology, 4(4), 329-335. https://doi. org/10.3844/ajbbsp.2008.329.335

Moreno, J., Simpson, R., Baeza, A., Morales, J., Muñoz, C., Sastry, S., \& Almonacid, S. (2012). Effect of ohmic heating and vacuum impregnation on the osmodehydration kinetics and microstructure of strawberries (cv. Camarosa). LWT - Food Science 
and Technology, 45(2), 148-154. https://doi.org/10.1016/j. Iwt.2011.09.010

NAGEL, C. W., \& PATTERSON, M. E. (1967). Pectic Enzymes and Development of the Pear (Pyrus communis). Journal of Food Science, 32(3), 294-297. https://doi.org/10.1111/j.1365-2621.1967. tb01316.x

Paniagua, C., Posé, S., Morris, V. J., Kirby, A. R., Quesada, M. A., Mercado, J. A., ... MOHR, W. P. (2014). Fruit softening and pectin disassembly: An overview of nanostructural pectin modifications assessed by atomic force microscopy. Annals of Botany, 114(6), 1375-1383. https://doi.org/10.1093/aob/mcu149

Park, M. H., Sangwanangkul,P., \& Bae, D. R. 2018. Changes in carotenoid and chlorophyll content ofblack tomatoes (Lycopersicone sculentumL.)during storage at various temperatures. Saudi Journal of Biological Sciences, 25 (1): 57-65 . https://doi. org/10.1016/j.sjbs.2016.10.002

Pinheiro, J., Alegria< C., Abreu, M., Gonçalves, E.M., \& Silva, C.L.M. 2013. Kinetics of changes in the physical quality parameters of fresh tomato fruits (Solanum lycopersicum, cv. 'Zinac') during storage Journal of Food Engineering 114:338-345. http:// dx.doi.org/10.1016/j.jfoodeng.2012.08.024.

Ponce-Valadeza, M., Escalona-Buendíab, H. B., Villa-Hernándeza, J. M., de León-Sáncheza, F. D., Rivera-Cabreraa, F., Alia-Tejacalc, I., \& Pérez-Floresa, L. J. (2016). Effect of refrigerated storage $(12.5 \mathrm{C})$ on tomato (Solanum lycopersicum) fruit flavor: A biochemical and sensory analysis. Postharvest Biology and Technology 111: 6-14. http://dx.doi.org/10.1016/j.postharvbio.2015.07.010

Požrl, T., Žnidarčič, D., Kopjar, M., Hribar, J., \& Simčič, M. (2010) Change of textural properties of tomatoes due to storage and storage temperatures. Journal of Food, Agriculture and Environment, 8(2), 292-296.

Rosenthal, A. J. (2010). Texture profile analysis - How important are the parameters? Journal of Texture Studies, 41(5), 672-684 https://doi.org/10.1111/j.1745-4603.2010.00248.x

Sañudo-barajas, J. A., Lipan, L., Cano-lamadrid, M., Vélez, R., Rocha, D., Noguera-artiaga, L., \& Sánchez-, L. (2019). Texture. In Postharvest Physiology and Biochemistry of Fruits and Vegetables. https://doi.org/10.1016/B978-0-12-813278-4.00014-2

Sheehy, R. E., Kramer, M., \& Hiatt, W. R. (1988). Reduction of polygalacturonase activity in tomato fruit by antisense RNA Proceedings of the National Academy of Sciences, 85(23), 8805-8809. https://doi.org/10.1073/pnas.85.23.8805

Sun, Y., Kang, X., Chen, F., Liao, X., \& Hu, X. (2019). Mechanisms of carrot texture alteration induced by pure e ff ect of high pressure processing. Innovative Food Science and Emerging Technologies, 54(17), 260-269. https://doi.org/10.1016/j. ifset.2018.08.012

Supriyadi, S., Suzuki, M., Wu, S., Tomita, N., Fujita, A., \& Watanabe, N. (2003). Biogenesis of volatile methyl esters in snake fruit (salacca edulis, reinw) cv. Pondoh. Bioscience, Biotechnology and Biochemistry, 67(6), 1267-1271. https://doi.org/10.1271/ bbb.67.1267

Supriyadi, Suhardi, Suzuki, M., Yoshida, K., Muto, T., Fujita, A., \& Watanabe, N. (2002). Changes in the Volatile Compounds and in the Chemical and Pondoh during Maturation. Journal of Agriculture and Food Chemistry, 50, 7627-7633.

Szychowski, P. J., Frutos, M. J., Burló, F., Pérez-López, A. J., Carbonell-
Barrachina, Á. A., \& Hernández, F. (2015). Instrumental and sensory texture attributes of pomegranate arils and seeds as affected by cultivar. LWT - Food Science and Technology, 60(2), 656-663. https://doi.org/10.1016/j.lwt.2014.10.053

Taylor, N. S., Hammermeister, A. M., Vasantha Rupasinghe, H. P., \& Pruski, K. (2013). Characterization of ribes nigrum in relation to fruit maturity and genotype. Acta Horticulturae, 1001, 199-206.

Chauhan, O. P., Raju, P. S., Dasgupta, D. K., \& Bawa, A. S. (2006). Instrumental Textural Changes In Banana (Var. Pachbale) During Ripening Under Active And Passive Modified Atmosphere International Journal of Food Properties Instrumental, 9, 237 253. https://doi.org/ : 10.1080/10942910600596282

Tolesaa, G .N., Workneha, T .S., \& Melesseb, S. F. (2018). Modelling effects of pre-storage treatments, maturity stage, low-cost storage technology environment and storage period on the quality of tomato fruit. Cyta - Journal Of Food, 16(1), 271-280. https://doi.org/10.1080/19476337.2017.1392616

Verma, C., Kumar Mani, A., \& Mishra, S. (2017). Biochemical and Molecular Characterization of Cell Wall Degrading Enzyme, Pectin Methylesterase Versus Banana Ripening: An Overview. Asian Journal of Biotechnology, 9(1), 1-23. https://doi.org/10.3923/ ajbkr.2017.1.23

Watson, C. F., Zheng Liansheng, \& DellaPenna, D. (1994). Reduction of tomato polygalacturonase beta subunit expression affects pectin solubilization and degradation during fruit ripening. Plant Cell, 6(11), 1623-1634. https://doi.org/10.1105/tpc.6.11.1623 Wei, J., Ma, F., Shi, S., Qi, X., Zhu, X., Yuan, J., ... Labavitch, J. M. (2010). Changes and postharvest regulation of activity and gene expression of enzymes related to cell wall degradation in ripening apple fruit. Postharvest Biology and Technology, 56(2), 147-154. https://doi.org/10.1016/j.postharvbio.2009.12.003

Wei, J., Qi, X., Cheng, Y., \& Guan, J. (2015). Difference in activity and gene expression of pectin-degrading enzymes during softening process in two cultivars of Chinese pear fruit. Scientia Horticulturae, 197, 434-440. https://doi.org/10.1016/j. scienta.2015.10.002

Wu, X., Yu, M., Huan, C., Ma, R., \& Yu. Z. 2018. Regulation of the protein and gene expressions of ethylene biosynthesis enzymes under different temperature during peach fruit ripening. Acta Physiologiae Plantarum, 40:52. https://doi.org/10.1007/ s11738-018-2628-5.

Xie, F., Yuan, S., Pan, H., Wang, R., Cao, J., \& Jiang, W. (2017). Effect of yeast mannan treatments on ripening progress and modification of cell wall polysaccharides in tomato fruit. Food Chemistry, 218, 509-517. https://doi.org/10.1016/j.foodchem.2016.09.086

Xin, Y., Chen, F., Yang, H., Zhang, P., Deng, Y., \& Yang, B. (2010). Morphology, profile and role of chelate-soluble pectin on tomato properties during ripening. Food Chemistry, 121(2), 372-380. https://doi.org/10.1016/j.foodchem.2009.12.038

Yaman, Ö., \& Bayoindirli, L. (2002). Effects of an edible coating and cold storage on shelf-life and quality of cherries. LWT Food Science and Technology, 35(2), 146-150. https://doi. org/10.1006/fstl.2001.0827

Zahir, K., Nejib, G., Vandita, S., R, M. S., \& Lyutha, A. (2013). Instrumental Texture Profile Analysis of Date-Tamarind Fruit Leather with Different Types of Hydrocolloids. 19(4), 531-538. 